\title{
Criminalization On Missing Returned Product Transaction In Tourism Industry Perspective
}

\author{
I Nyoman Putu Budiarta, Rathna Anggreany Nangi, and I Nyoman Sugiartha \\ \{info@warmadewa.ac.id\} \\ Universitas Warmadewa, Denpasar
}

\begin{abstract}
A new e-commerce is clearly and specifically regulated on March 11, 2014 by enacting Law Number 7 of 2014 concerning Trade. Previously, ecommerce rules only relied on Electronic Information and Transaction information or ITE Law and Civil Code in its implementation. But after Law No. 7 of 2014 concerning Trade is being ratified by the government, thus the principle of Lex specialis derogat legi applies to the law which regulates specifically regarding e-commerce. This study aims to describe the implementation of E-commerce law based on Law Number 19 of 2016 concerning Electronic Information and Transactions and to identify the impacts of criminal settlement in a missing returned product transaction in tourism industry perspective between PT. Fashion Marketplace Indonesia and PT. Volcom Indonesia. The models approach to data in this study consists of an observation approach or observation in the field, a statutory approach and an analytical approach. The data are analyzed by using inductive method. Inductive approaches are generally associated with qualitative research. From this study found that in its implementation, E-commerce experiences problems, especially those related to contracts, consumer protection, protection of business actors, tax jurisdiction and digital signatures. The solution to the problem of missing return product has been in an effort to take a non-ligative solution to prevent a wider impact, especially in the world of tourism. But it is also possible to take the ligitation settlement, because law enforcement has a great influence; on the security situation and the state's image in ensuring a sense of security for tourists and maintaining public trust in the tourism sector. Therefore, solving ecommerce problems should take non-ligitation methods, or Alternative Dispute Resolution, so as to maintain public trust, especially consumers. The state, in this case the government as the state organizer, should form a special institution that can carry mediation settlement if there are cases in E-Commerce transactions. This is important to maintain the image of state security, which has a big influence in the world of tourism.
\end{abstract}

Keywords: Criminalization, e-commerce, missing return product, tourism 


\section{Introduction}

This research is motivated by the existence of missing returned product transactions that occur in an online order transaction process in which Law No. 19 of 2016 concerning Information and Electronic Transactions has an important role in the process of dispute resolution between the two parties.

Purchasing and selling online is known as e-commerce. A consumer can be protected his rights related to the purchasing and selling process by e-commerce. If the goods or services received by consumer does not match the information received, consumer can ask for compensation or returning to the seller and the seller is also obliged to provide compensation and / or returning if the goods and / or services are received or used not in accordance with the agreement [1]. A Returned product can be understood as products or goods that have been purchased by purchaser but because the product does not match the one offered by the seller therefore the products are returned to the seller.

E-commerce can be interpreted simply as an electronic transaction [2]. Moreover, Ecommerce transactions that occur within the community are purchasing and selling activities carried out across regional boundaries, people do not need to meet in person to shop or buy an item that is needed. The use of E-commerce media in world of commerce has had an impact on the international community in general and the Indonesian people in particular. One of the reasons why transactions through e-commerce are more desirable than conventional trading because by using e-commerce transactions can be done quickly, easily, and lower costs [3]. Unfortunately in shopping and making transactions online it is not infrequently for people to have loss [4]. The aforementioned loss causes a criminal acts in a missing returned product transaction. Based on the criminal act, according to Utilitarian and Retributivist views, a convicted act has beneficial consequences that can be proven and can be achieved if the goal of criminalization is carried out using a measure of justice principles.

Based on the background above, the formulations of the problem in this study are 1) How is the implementation of E-commerce law based on Law Number 19 of 2016 concerning Electronic Information and Transactions? 2) What is the impacts of criminal settlement in a missing returned product transaction in perspective of the tourism industry of PT. Fashion Marketplace Indonesia on PT. Volcom Indonesia?

A number of related studies had been conducted with different purposes, one of them studies the juridical review regarding E-commerce transactions based on civil law perspective and law number 7 of 2014 concerning trade [5]. The study examined E-commerce transactioan as this research carried out, however that E-commerce transaction on the latest related study is based on perspective of law civil. This is what researchers thought to carry a study in which the study of E-commerce transaction is based on tourism industry perspective. Another related study is about legal enforcement against fraudulent acts in electronic based transactions [1]. There are many laws governing fraud in E-commerce today, one of which in the research above is the Criminal Law Code. Therefore, this present study will review the Law number 19 of 2016 which regulates criminal acts in e-commerce.

Considering the background of problems in question above, therefore, the aims of this study that can be made are to describe the implementation of E-commerce law based on Law Number 19 of 2016 concerning Electronic Information and Transactions and to identify the impacts of criminal settlement in a missing returned product transaction in tourism industry perspective between PT. Fashion Marketplace Indonesia and PT. Volcom Indonesia. 


\section{Method}

This research is an empirical/sociological law research [6]. The models approach is used to describe the implementation of E-commerce law based on Law Number 19 of 2016 concerning Electronic Information and Transactions and to identify the impacts of criminal settlement in a missing returned product transaction in tourism industry perspective between PT. Fashion Marketplace Indonesia and PT. Volcom Indonesia in this study consists of an observation approach or observation in the field, a statutory approach and an analytical approach. The legal material used in this study is Law number 19 of 2016. The data are analyzed by using inductive method. Inductive approaches are generally associated with qualitative research.

\section{Discussion}

\subsection{E-Commerce implementation based on Law number 19 of 2016}

In this study, based on observation in the field, PT. Volcom Indonesia as a supplier and producer cooperates with PT. Fashion Marketplace Indonesia as a party that offers and markets goods that are produced by PT. Volcom Indonesia based on a Memorandum of Undesrstanding, in accordance with the agreement principle in general. Electronic contract (econtract) is a contract that occurs due to an electronic commercial (e-commerce) transaction. The validity of a sale and purchase agreement through the internet is similar with the validity of a conventional agreement, that is the fulfillment of the provisions contained in article 1320 of the Indonesian Criminal Code concerning the legal conditions of the agreement. The difficulty of proving legal skills in the e-commerce transaction process can be overcome by the provision in article 65 of law no. 7 of 2014 that every party in an E-commerce transaction must state their identity [5]. In researchers' opinion, in discussing the first legal issue of this study is used legal certainty theory and criminalization theory as the theories of analysis. According to Kelsen, law is a norm system. Norms are statements that emphasize a "must" or das sollen aspects, including some rules about what should be done. Norms are deliberative human products and actions. Laws that contain general rules serve as guidelines for individuals behaving in society, both in relationships with fellow individuals and in relations with society. These rules become a limit for society in burdening or taking action to individuals. The existence of these rules and the implementation of these rules give rise to legal certainty. Regulations regarding e-commerce have been regulated in Law number 7 of 2014 concerning Trade and Law Number 19 of 2016 concerning Informatics and Electronic Transactions. In this law has been regulated clearly and firmly about transactions in ECommerce, but in its implementation it should be a concern of all parties, both E-Commerce organizers and other interested parties. Furthermore, Law Number 19 of 2016, it has also stipulated about criminal sanctions-for every person who commits an offense.

\subsection{The Impacts of Criminal Settlement in Missing Returned Product Transactions in Tourism Industry Perspective}

Criminal law as a public law is divided into material criminal law and formal criminal law or criminal procedure law. Material criminal law determines what actions can be convicted, who can be convicted and what criminal can be imposed [7]. 
The reasons for criminal abolition consist of two types, they are justification and forgiveness. There is a justification if there is no unlawful character, while there is a forgiving reason if there is no reprehensible character. In principle, the parameter of whether a person is accounted for or not accounted for is the legal interest to be protected from the formation of legal norms that are already in the legislation. The legal interest to be protected in relation to unlawful character is an embodiment of legality principle, that a person can be accounted for because of the existence of a norm system in legislation. On the other hand, a person can not be accounted for because of justification is also based on moral values that live in society that reduced in the law. Online business has become a trend now, but it opens up chances for those who are not responsible for committing a crime that causes loss to others [8]. An effort to tackle e-commerce crime today must be prioritized. Indonesia must anticipate the development of this technological crime with a legal that has a certainty. It should be understood that in the use of electronic systems there are two basic things that must be considered. First, technology is the result of human findings which will certainly have weaknesses in the technical system. Second, technology besides having weaknesses in its technical system also has uncertainty in terms of guaranteed legal certainty [9].

A cyberlaw urgency for Indonesia is required to lay the legal and cultural foundation for Indonesian people to enter and become actors in the community of people who utilize sophistication in the field of information technology. The existence of cyberlaw will help businessmen and auditors to carry out their duties. Cyberlaw provides guidelines for internet users. Internet users can use the internet freely when there are no binding and "forced" rules. However, the existence of clear rules or laws will restrict internet users from committing crimes and fraud by using the internet. For auditors, besides using a standard in auditing information systems, clear and firm laws can minimize the existence of crime and fraud so as make it easy for auditors to track the crime. The security guarantee provided will foster user confidence so that the implementation of e-commerce can run well, especially in Indonesia.

Based on the observation carried by the researchers at the research location, that the steps of settlement of missing return product transaction of PT. Fashion Marketplace Indonesia to PT. Volcom Indonesia consist of:

1. Reconciliation of sales data at PT. Fashion Marketplace Indonesia and PT. Volcom Indonesia, with a deadline in accordance with the agreement for 30 working days. If within 30 days PT. Fashion Marketplace Indonesia and PT. Volcom Indonesia found that there was indeed no difference in sales through reconciliation of data from each warehouse because there was no intentional factor, so the adjustment sales report would be made in the following month.

2. If the reconciliation of the first sales data does not or has not yet found the cause of the difference between PT. Fashion Marketplace Indonesia and PT. Volcom Indonesia, internal reconciliation will be carried as a second reconciliation, with a period of 7 working days in each warehouse between PT.Fashion Marketplace Indonesia warehouse and PT.Volcom Indonesia Warehouse and if within a 7-day period the difference has been found, then the adjustment sales repot will be carried in the following month.

In the second data reconciliation the difference has not yet been found, an external reconciliation will be carried out externally from PT. Volcom Indonesia to PT. Fashion Market Indonesia based on data of goods returns at warehouse by consumers to PT. Fashion Market Indonesia, with a period of 7 working days later. And if it has been found, the adjustment sales repot will be done next month. Whereas if there is an intentional factor from PT. Fashion Marketplace Indonesia to postpone the return of goods that have been returned by consumers to PT. Fashion Marketplace Indonesia, therefore PT. Volcom Indonesia will make 
an effort to resolve it by deliberation, but if it is not successful then mediation efforts will be taken- before any legal actions is taken either through civil lawsuits or criminal charges, if there are criminal factors.

In related study afortmention, the settlement of disputes that occur in an online sale and purchase agreement if there is a party that loses therefore, he asks for compensation for default. Compensation for the default can be in the form of fulfillment of the agreement and compensation, cancellation of the agreement accompanied by compensation. Steps that can be taken are litigation or non-litigation according to article 65 paragraph 5 of Law number 7 of 2014 [5]. Unfortunately, the settlement to the problem of missing return product between PT. Fashion Marketplace Indonesia with PT. Volcom Indonesia has so far been pursuing a nonlitigation settlement, in order to prevent a wider impact, especially in the world of tourism. With the non-litigation settlement, up to now it still has not been given a sollution.

In the opinion of researchers, in analyzing the second legal issue in this study, by using the theory of justice raised by Aristoteles as the theory of analysis, that law enforcement must be oriented to the interests of the community and also must pay attention to the moral principles that have to be maintained theoretically related to theories of distributive justice and corrective justice. This is in line with the opinion of researchers that in law enforcement is also required the existence of a moral, the relationship of moral and law enforcement that determines a success or failure in law enforcement as expected by the legal objectives [10].

Distributive justice, according to Aristoteles, refers to the principle that everyone in society must get equal shares regarding to assets or anything that is divisible among members of the community. In connection with the missing return product, which occurs in E-Commerce, in the case of criminalization to the parties proven to have committed criminal must provide a sense of justice for the injured and also pay attention to aspects outside of the law such as giving a sense of benefit to all parties.

\section{Conclusions}

Based on the analysis has been carried by using inductive method in this research entitled Criminalization on Missing Returned Product Transactions in Tourism Industry Perspective, as the problem formulation above, therefore it can be made conclusions as follows:

1. Regulations regarding E-Commerce have been regulated in Law Number 7 of 2014 concerning Trade and Lae Number 19 of 2016 concerning Informatics and Electronic Transactions. In this law has been regulated clearly and firmly about transactions in ECommerce, on the other side both of E-Commerce providers and other interested parties are not in accordance with the existing provisions because there are still various problems that loss one of the parties.

2. The settlement to the problem of missing return product between PT. Fashion Marketplace Indonesia with PT. Volcom Indonesia has so far been pursuing a nonlitigation settlement, in order to prevent a wider impact, especially in the world of tourism. With the non-litigation settlement, up to now it still has not been given a sollution for PT. Volcom Indonesia, which suffered a loss in the problem of missing returned products, therefore PT. Volcom Indonesia has not received a sense of justice and benefits in the non-litigation settlement process. 


\section{References}

[1] T. Y. Rahmanto, "Penegakan Hukum Terhadap Tindak Pidana Penipuan Berbasis Transaksi Elektronik," vol. 19, no. 1, 2019.

[2] B. Kienan, Small Business Solution, E-commerce untuk perusahaan kecil, alih Bahasa Frans Kowa. Jakarta: PT Elex Media Komputindo, 2001.

[3] M. S. Hotana, "Industri E-Commerce Dalam Menciptakan Pasar Yang Kompetitif Berdasarkan Hukum Persaingan Usaha," no. 1, 2018.

[4] A. R. Siregar and G. Y. K. S. S. Pahu, "Pengakuan Transaksi Elektronik E-commerce) Dalam Kerangka Hukum Perikatan Dan Kerangka Pembuktian, Keadilan Progresif,” vol. 8, no. 2, 2017.

[5] I. M. Solihah, Tinjauan Yuridis Mengenai Transaksi E-commerce Berdasarkan Perspektif Hukum Perdata dan Undang-Undang No 7 Tahun 2014 Tentang Perdagangan. Yogyakarta: Universitas Islam Negeri Sunan Kalijaga, 2017.

[6] S. Soekanto, Pengantar Penelitian Hukum. Jakarta: Universitas Indonesia Press, 1986.

[7] Muchsin, Ikhtisar Hukum Indonesia. Bandung: Eresco, 2010.

[8] A. Wahidi and M. Labib, Kejahatan Mayantara (Cybercrime). Bandung: Refika Aditama, 2005.

[9] Editorial Jurnal Hukum Bisnis, "E-commerce Meningkatkan Efisiensi," J. Huk. Bisnis, vol. 18, 2002.

[10] Muladi, Hak Asasi Manusia. Bandung: PT. Refika Aditama, 2009. 